\title{
Perdarahan uterus abnormal - menoragia pada masa remaja
}

\author{
John J. E. Wantania \\ Bagian/SMF Obstetri dan Ginekologi Fakultas Kedokteran \\ Universitas Sam Ratulangi - RSUP Prof. Dr. R. D. Kandou Manado \\ Email: john_w_md@yahoo.com
}

\begin{abstract}
WHO identifies adolescence as a period in human growth and development that occurs after childhood and before adulthood from age 10 to 19 years. Two large studies have shown that a greater increase in BMI in childhood is associated with earlier onset of puberty. In general, the age of menarche ranges relatively stable from 11 to 14 years with a median of 12.43 years. The average of menstrual cycle interval is 32.3 days in the first reproduction year. After that, the interval of menstrual cycles generally ranges from 21 to 45 days. Duration of menstruation is 7 days or less. The use of tampons or pads are generally three to six pieces per day. Abnormal uterine bleeding (AUB) is defined as a significant change in the pattern of menstruation or the volume of blood discharge, and is the most common complaint in women. In early adolescence, $75 \%$ of adolescents experience abnormal uterine bleeding. Heavy menstrual bleeding (HMB) as well as heavy and prolonged menstrual bleeding (HPMB) is the preferred term for excessive menstrual bleeding. Medical treatment is performed as the initial treatment as long as there is no contraindication. When the acute bleeding has been handled, it is recommended to arrange a transition in the long-term treatment
\end{abstract}

Keywords: menstruation, teens, abnormal uterine bleeding (AUB)

\begin{abstract}
Abstrak: WHO mengidentifikasi remaja sebagai periode pada pertumbuhan manusia dan perkembangan yang terjadi setelah masa kanak-kanak dan sebelum dewasa, dari umur 10 sampai 19 tahun. Dua studi besar telah membuktikan bahwa peningkatan IMT yang lebih besar pada masa kanak-kanak berhubungan dengan onset pubertas yang lebih awal. Usia menarche umumnya relatif stabil berkisar antara 11 dan 14 tahun dengan median 12,43 tahun. Interval siklus rata-rata ialah 32,3 hari pada tahun reproduksi pertama dan interval siklus mentruasi umumnya 21-45 hari. Lama menstruasi ialah 7 hari atau kurang. Penggunaan tampon atau pembalut umumnya tiga sampai enam buah per hari. Perdarahan uterus abnormal (PUA) adalah perubahan signifikan pada pola atau volume darah menstruasi dan merupakan hal yang paling banyak dikeluhkan oleh wanita. Pada awal usia remaja, 75\% remaja mengalami keluhan PUA. Perdarahan haid berat (heavy menstrual bleeding) dan perdarahan haid berat dan memanjang (heavy and prolonged menstrual bleeding) ialah istilah yang lebih sering digunakan untuk perdarahan haid yang berlebihan. Penanganan medis menjadi terapi awal bila tidak ada kontrindikasi. Bila perdarahan akut sudah ditangani, direkomendasikan untuk melakukan transisi pada penanganan jangka panjang.
\end{abstract}

Kata kunci: menstruasi, remaja, perdarahan uterus abnormal (PUA)

Menstruasi atau haid adalah hal yang akan dijalani oleh seorang remaja wanita, tetapi bila terjadi perdarahan uterus berlebihan maka hal tersebut berhubungan dengan tingkat kesakitan yang signifikan. Pasien remaja dan orang tuanya sering tidak memahami mengenai siklus atau pola haid normal. Remaja wanita dapat saja tidak 
mengetahui apa yang disebut normal dan enggan untuk berdiskusi dengan orang tua mengenai masalah haid. Sebagian remaja menganggap variasi haid merupakan sesuatu yang tidak normal dan mencari bantuan medis. Remaja lainnya mungkin tidak sadar bahwa pola haid mereka tidak normal dan merupakan bagian dari kondisi medis lain yang membutuhkan perhatian. ${ }^{1}$

\section{Batasan remaja}

WHO mengidentifikasi remaja sebagai periode pada pertumbuhan dan perkembangan manusia yang terjadi setelah masa kanak-kanak dan sebelum dewasa, dari usia 10 sampai 19 tahun. Departemen Kesehatan RI tahun 2009 membagi kategori umur remaja menjadi masa remaja awal yaitu 12-16 tahun dan masa remaja akhir yaitu 17-25 tahun.

\section{Siklus haid normal}

Onset pubertas dan menarke (menarche) umumnya terjadi di usia yang lebih lanjut pada remaja di negara yang kurang berkembang. Dua studi besar telah membuktikan bahwa peningkatan indeks massa tubuh (IMT) yang lebih besar pada masa kanak-kanak berhubungan dengan onset pubertas yang lebih awal. ${ }^{2}$ Walaupun terdapat variasi di seluruh dunia, usia ratarata menarke umumnya relatif stabil yaitu antara 11 dan 14 tahun dengan usia median 12,43 tahun. Interval siklus rata-rata ialah 32,3 hari pada tahun reproduksi pertama dan selanjutnya interval siklus mentruasi umumnya berkisar 21-45 hari. Lama menstruasi ialah 7 hari atau kurang dengan penggunaan tampon atau pembalut umumnya tiga sampai enam buah perhari. ${ }^{3}$

\section{Perdarahan uterus abnormal (PUA)}

Perdarahan uterus abnormal (PUA) didefinisikan sebagai perubahan signifikan pada pola atau volume darah menstruasi. Perdarahan uterus abnormal merupakan hal yang paling banyak dikeluhkan oleh wanita. Pada awal usia remaja, $75 \%$ remaja mengalami keluhan PUA. Perdarahan haid berat (heavy menstrual bleeding; HMB) serta perdarahan haid berat dan memanjang (heavy and prolonged menstrual bleeding; HPMB) ialah istilah yang lebih dipilih untuk perdarahan haid berlebihan; istilah ini lebih dapat dipahami oleh pasien. ${ }^{4}$

Umumnya PUA pada remaja berhubungan dengan imaturitas aksis hipotalamus-pituitari-ovarium dan perdarahan anovulatorik yang terjadi tidak disertai oleh kelainan anatomik atau hormonal. $^{5}$

Tabel 1. Penyebab HMB atau HPMB pada remaja $^{5}$

\begin{tabular}{l} 
Causes of HMB or HPMB in \\
adolescents \\
\hline Endocrinologic \\
- Dysfunctional uterine bleeding \\
(immaturity of the axis) \\
- Polycystic ovary syndrome \\
- Thyroid disturbance \\
Hematologic \\
- Von Willebrand disease \\
- Platelet function disorder \\
- Connective tissue disorder (eg. \\
- Ehler Danlos syndrome) \\
- Thrombocytopenia \\
- Hemophilia carriage \\
Pregnancy complication \\
Sexually transmitted infection/Pelvic \\
inflammatory diseaase \\
Medication \\
- Hormonal contraceptives \\
- Antidepressants/antipsychotics \\
- Platelet inhibitors \\
- Anticoagulants \\
Trauma \\
Systemic illness
\end{tabular}

Abbreviations: HMB, heavy menstrual bleeding; HPO, hypothalamic pituitary ovarian; HPMB, heavy and prolonged menstrual bleeding

Investigasi dan manajemen PUA pada wanita umur reproduktif tidak hamil sering membingungkan dan berdasarkan pada nomenklatur yang tidak konsisten sehingga 
perlu diciptakan metode terstandarisasi untuk kategorisasi berbagai etiologi potensial. Federation of International Gynecology and Obstetrics (FIGO) telah mengklasifikasikan etiologi PUA menjadi 9 kategori utama yang disingkat menjadi
PALM-COEIN: polyp, adenomyosis, leimyoma, malignancy and hyperplasia, coagulopathy, ovulatory dysfunction, endometrial, iatrogenic, dan not yet classified. $^{6}$

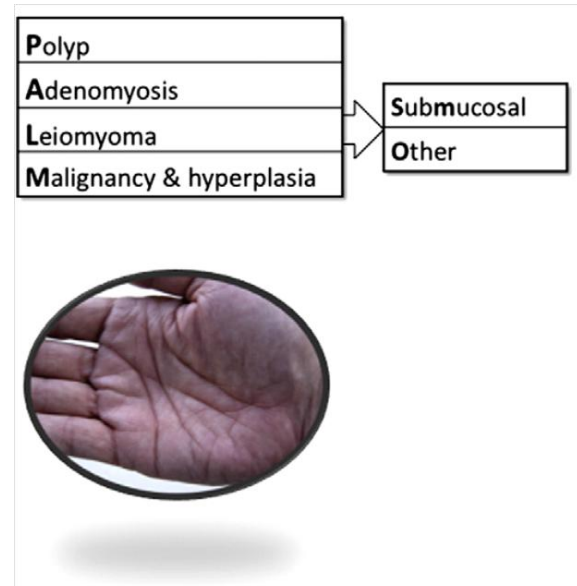

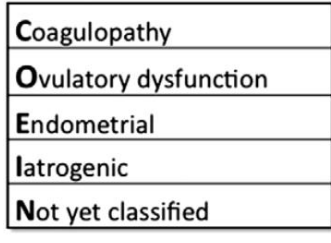

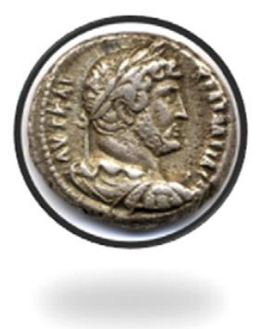

Gambar 1. Sistem klasifikasi dasar. Sistem dasar terdiri dari 4 kategori etiologi yang dapat terdefinisi secara visual anatomik (PALM) dan 4 etiologi yang tidak berhubungan dengan kelainan struktural (COEIN). Sumber: FIGO Working Group on Menstrual Disorder, $2011 .^{6}$

Berdasarkan klasifikasi dari FIGO, penyebab PUA tersering ialah koagulopati dan disfungsi ovulatori. Penyebab anatomik HMB seperti polip atau malformasi vaskular jarang terjadi pada remaja tetapi dapat dipertimbangkan pada kasus dimana terapi tidak memberikan hasil memuaskan. Walaupun beberapa kelainan perdarahan dapat terlihat pada masa kanak-kanak awal, HMB memungkinkan untuk menjadi gejala yang mengarah pada diagnosis kelainan perdarahan. Penyakit Von Willebrand, defisiensi penyimpanan platelet dan kelainan fungsi platelet lainnya, kelainan jaringan pengikat seperti Ehlers-Danlos syndrome (EDS), trombositopenia, karier hemophilia, dan defisiensi faktor pembekuan dapat menyebabkan HMB. Pada remaja dengan $\mathrm{HMB}$, prevalensi penyakit von Willebrand dapat mencapai $36 \%$ dan prevalensi disfungsi platelet $44 \%{ }^{7}$

\section{Koagulopati}

Istilah koagulopati mencakup spektrum kelainan hemostasis sistemik yang dapat berhubungan dengan PUA. Beberapa penelitian memperlihatkan bahwa kurang lebih $13 \%$ wanita dengan HMB memiliki kelainan hemostatis sistemik yang dapat dideteksi secara biokimiawi, paling sering yaitu penyakit von Willebrand. ${ }^{8}$

Disarankan untuk mencurigai kelainan hemostasis bila ditemukan HMB sejak menarke; salah satu dari riwayat perdarahan postpartum, perdarahan yang berhubungan dengan operasi, perdarahan yang berhubungan dengan tindakan pada pengobatan gigi; serta dua dari adanya memar 1-2 kali per bulan, epistaksis 1-2 kali per bulan, perdarahan gusi yang sering, dan riwayat perdarahan pada keluarga. ${ }^{9}$

\section{Disfungsi ovulatori (ovulatory dysfunction)}

Disfungsi ovulatori dapat menyebabkan PUA dengan gejala gangguan pola dan jumlah perdarahan yang pada beberapa kasus dapat menyebabkan HMB. Pada beberapa negara kelainan ovulatori mencakup mayoritas kasus yang dahulu 
disebut dengan perdarahan uterus disfungsional (dysfunctional uterine bleeding; DUB). Kelainan ovulasi dapat muncul sebagai sebuah spektrum kelainan haid - mulai dari amenore sampai spotting, sampai episode HMB ekstrim yang memerlukan intervensi medis maupun operasi. $^{10}$

Pada remaja, aksis hipotalamuspituitari-ovarium memerlukan waktu untuk matang setelah menarke, yang dapat menyebabkan anovulasi. Pada 2 tahun pertama setelah menarke $55-82 \%$ siklus bersifat anovulatorik, dan pada tahun ke-4 dan ke-5 mengalami penurunan menjadi $20 \%$ siklus. Diperkirakan $95 \%$ perdarahan uterus disfungsional pada remaja disebabkan oleh anovulasi. ${ }^{11}$

Walaupun kebanyakan kelainan ovulatori tidak memiliki etiologi yang jelas, banyak yang mempunyai dasar endokrinopati (contoh: sindrom polikistik ovari, hipotirodisme, hiperprolaktinemia, stres mental, obesitas, anoreksia, penurunan berat badan atau latihan ekstrim yang berhubungan dengan regimen latihan atletik). Pada beberapa kasus kelainan ini dapat bersifat iatrogenik, disebabkan oleh steroid atau obat yang memengaruhi metabolism dopamin seperti phenothiazine dan antidepresan trisiklik. Kelainan ovulatori yang tidak dapat dijelaskan penyebabnya sering terjadi pada umur reproduksi ekstrim seperti saat masa transisi remaja dan menopause. ${ }^{12}$

\section{Anamnesis dan pemeriksaan fisik}

Pada anamnesis perlu diketahui usia menarke, frekuensi, durasi, dan sifat perdarahan. Kuantifikasi perdarahan yang terjadi dapat menjadi masalah karena remaja memiliki pengalaman terbatas dalam menilai perdarahan. Sebaiknya ditanyakan berapa jumlah produk tampon maupun pembalut yang digunakan. Pada remaja yang mengeluhkan haid yang banyak perlu ditanyakan riwayat mudah memar, perdarahan yang sulit berhenti pada luka minor, epistaksis yang sering atau sulit dikontrol, atau perdarahan hebat setelah operasi. $^{7}$

Riwayat perdarahan pada keluarga termasuk riwayat perdarahan postpartum penting diketahui untuk mencari kelainan perdarahan pada keturunan. Anamnesis mengenai riwayat penggunaan obat-obat dan kontrasepsi hormonal juga perlu ditanyakan.

Pemeriksaan fisik harus sebaiknya dilakukan walaupun sebagian besar kasus normal. Takikardi dan hipotensi dapat memberikan petunjuk ketidakstabilan hemodinamik akut yang memerlukan intervensi cepat. Adanya takikardia, penampilan pucat, atau bunyi bising pada auskultasi jantung mengarah pada anemia. Petekia atau memar yang berlebihan dapat mengarah pada defek platelet atau kelainan perdarahan lainnya. Pemeriksaan inspeksi pada genitalia cukup untuk menegakkan diagnosis pada kebanyakan pasien. Pemeriksaan bimanual dan spekulum disarankan pada pasien yang aktif secara seksual atau pada pasien yang tidak mengalami respon terhadap terapi..$^{5}$

\section{Evaluasi laboratorium}

Evaluasi laboratorium direkomendasikan pada pasien dengan PUA. Seluruh pasien dengan kelainan pada pemeriksaan darah awal atau hasil positif pada kelainan pembekuan darah sebaiknya dilakukan pemeriksaan penyakit von Willebrand dan kelainan koagulopati lainnya termasuk faktor VIII, antigen faktor von Willebrand dan aktivitas kofaktor ristocetin von Willebrand. Pemeriksaan kelainan tiroid, kelainan hati, sepsis atau leukemia diindikasikan bila ditemukan gejala klinis. ${ }^{1}$

Pada pasien dengan keluhan perdarahan yang dinilai dalam batas normal, pemeriksaan hemoglobin telah cukup untuk mendeteksi anemia. Pemeriksaan darah lengkap dengan hitung diferensiasi sel darah putih dan hitung platelet sebaiknya dilakukan pada pasien yang anamnesis dan pemeriksaan fisiknya mengarah pada HMB dan anemia. Pemeriksaan cadangan besi seperti penilaian kadar feritin dapat membantu 
menilai terapi pengganti besi. ${ }^{5}$

Jika kelainan perdarahan dicurigai sebaiknya dilakukan pemeriksaan waktu protrombin dan waktu tromboplastin parsial teraktivasi (PT dan APTT). Karena pemeriksaan ini tidak selalu memberikan nilai abnormal pada pasien dengan kelainan perdarahan sedang, pemeriksaan tambahan dapat dilakukan untuk menapis penyakit von Willebrand termasuk faktor VIII, antigen faktor von Willebrand (VWF:Ag) dan aktivitas kofaktor ristocetin (VWF:RCo). Nilai VWF:Ag dan VWF:RCo dibawah 30 IU/dL memberikan diagnosis pasti untuk penyakit von Willebrand. ${ }^{13}$

Tabel 2. Pemeriksaan laboratorium pada evaluasi pasien PUA. ${ }^{1}$

\begin{tabular}{|c|c|}
\hline aboratory testing for the evalu: & of patients with acute abnormal uterine bleedir \\
\hline Laboratory evaluation & Specific laboratory tests \\
\hline Initial laboratory testing & $\begin{array}{l}\text { Complete blood count } \\
\text { Blood type and cross match } \\
\text { Pregnancy test }\end{array}$ \\
\hline $\begin{array}{l}\text { Initial laboratory evaluation for } \\
\text { disorders of hemostasis }\end{array}$ & $\begin{array}{l}\text { Partial thromboplastin time } \\
\text { Prothrombin time } \\
\text { Activated partial thromboplastin time } \\
\text { Fibrinogen }\end{array}$ \\
\hline $\begin{array}{l}\text { Initial testing for von Willebrand } \\
\text { disease* }\end{array}$ & $\begin{array}{l}\text { von Willebrand factor antigen } \dagger \\
\text { Ristocetin cofactor assay } \dagger \\
\text { Factor VIII } \dagger\end{array}$ \\
\hline Other laboratory tests to consider & $\begin{array}{l}\text { Thyroid-stimulating hormone } \\
\text { Serum iron, total iron binding capacity, and ferritin } \\
\text { Liver function tests } \\
\text { Chlamydia trachomatis }\end{array}$ \\
\hline
\end{tabular}

\footnotetext{
*Adult women who receive positive results for risk of bleeding disorders or who have abnormal initial laboratory test results for disorders of hemostasis should undergo testing for von Willebrand disease. Adolescents with heavy menses since menarche who present with acute abnormal uterine bleeding also should undergo testing for von Willebrand disease.

$\dagger$ Consultation with a hematologist can aid in interpreting these test results. If any of these markers are abnormally low, a hematologist should be consulted.
}

\section{Penatalaksanaan}

Pemilihan terapi pada PUA akut tergantung pada kondisi umum, etiologi yang diduga, pertimbangan fertilitas pada masa mendatang, dan riwayat medis pasien. Dua tujuan utama dalam penanganan AUB akut ialah: 1) mengontrol episode perdarahan berat dan 2) mengurangi kehilangan darah haid pada siklus berikutnya. Terapi medis dipertimbangkan pada terapi awal tetapi beberapa situasi dapat memerlukan penanganan operatif. ${ }^{14}$ Penelitian mengenai penanganan PUA akut terbatas dan hanya satu terapi yaitu estrogen equine kojugasi (EEK) intravena yang disetujui oleh FDA Amerika Serikat untuk terapi PUA akut. ${ }^{1}$

\section{Penanganan medis}

Penanganan hormonal dipertimbangkan sebagai lini pertama terapi medis pada pasien dengan PUA akut tanpa kelainan perdarahan yang sudah diketahui atau dicurigai. Pilihan penanganan termasuk EEK intravena, pil kontrasepsi kombinasi (PKK), dan progestin oral. Kombinasi PKK dan progestin oral dalam regimen dosis multipel sering digunakan pada PUA akut. 
Tabel 3. medis pada Regimen terapi PUA akut ${ }^{1}$

\begin{tabular}{|c|c|c|c|c|}
\hline Drug & Source & $\begin{array}{l}\text { Suggested } \\
\text { dose }\end{array}$ & Dose schedule & $\begin{array}{l}\text { Potential contraindications } \\
\text { and precautions according to } \\
\text { FDA labeling* }\end{array}$ \\
\hline $\begin{array}{l}\text { Conjugated } \\
\text { equine } \\
\text { estrogren }\end{array}$ & 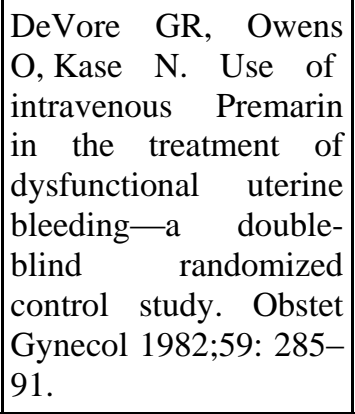 & $25 \mathrm{mg}$ IV & $\begin{array}{l}\text { Every } 4-6 \text { hours } \\
\text { for } 24 \text { hours }\end{array}$ & $\begin{array}{l}\text { Contraindications } \\
\text { but are not limited, to breast } \\
\text { cancer, active or past venous } \\
\text { thrombosis or arterial } \\
\text { thromboembolic disease, } \\
\text { and liver dysfunction or } \\
\text { disease. The agent should be } \\
\text { used with caution in patients } \\
\text { with cardiovascular or } \\
\text { thromboembolic risk factors. }\end{array}$ \\
\hline $\begin{array}{l}\text { Combined oral } \\
\text { contraceptives } \dagger\end{array}$ & $\begin{array}{l}\text { Munro MG, Mainor N, } \\
\text { Basu R, Brisinger M, } \\
\text { Barreda L. Oral } \\
\text { medroxyprogesterone } \\
\text { acetate and combina- } \\
\text { tion oral contra- } \\
\text { ceptives for acute } \\
\text { uterine bleeding: a } \\
\text { randomized } \\
\text { controlled trial. Obstet } \\
\text { Gynecol } \\
\text { 2006;108:924-9. }\end{array}$ & $\begin{array}{l}\text { Monophasic } \\
\text { combined oral } \\
\text { contraceptive } \\
\text { that contains } \\
35 \mu \mathrm{g} \text { of } \\
\text { ethinyl } \\
\text { estradiol }\end{array}$ & $\begin{array}{l}\text { Three times } \\
\text { per day for } 7 \text { days }\end{array}$ & $\begin{array}{l}\text { ontraindications include, but are } \\
\text { not limited to cigarette, smoking } \\
\text { (in women aged \#5 years or } \\
\text { older), hypertension, history of } \\
\text { deep vein thrombosis or } \\
\text { pulmonary embolism, } \\
\text { known thromboembolic } \\
\text { disorders, cerebrovascular } \\
\text { disease, ischemic heart disease, } \\
\text { migraine with aura, current or } \\
\text { past breast cancer, severe liver } \\
\text { disease, diabetes with vascular } \\
\text { involvement, valvular heart } \\
\text { disease with complications, and } \\
\text { major surgery with prolonged } \\
\text { immobilization. }\end{array}$ \\
\hline $\begin{array}{l}\text { Medroxypro- } \\
\text { gesterone } \\
\text { acetate } \$\end{array}$ & \begin{tabular}{|l|} 
Munro MG, Mainor N, \\
Basu R, Brisinger M, \\
Barreda L. Oral \\
medroxyprogesterone \\
acetate and \\
combination oral \\
contraceptives for acute \\
uterine bleeding: a \\
randomized controlled \\
trial. Obstet Gynecol \\
2006;108:924-9.
\end{tabular} & $20 \mathrm{mg}$ orally & $\begin{array}{l}\text { Three times per } \\
\text { day for } 7 \text { days }\end{array}$ & $\begin{array}{l}\text { Contraindications include, but } \\
\text { are not limited to, active or past } \\
\text { deep vein thrombosis or } \\
\text { pulmonary embolism, active or } \\
\text { recent arterial thromboembolic } \\
\text { disease, current or past breast } \\
\text { cancer, and impaired liver } \\
\text { function or liver disease. }\end{array}$ \\
\hline $\begin{array}{l}\text { Tranexamic } \\
\text { acid }\end{array}$ & $\begin{array}{l}\text { James AH, Kouides } \\
\text { PA, Abdul-Kadir R, } \\
\text { Dietrich JE, Edlund M, } \\
\text { Federici AB, et al. } \\
\text { Evaluation } \\
\text { and MANAGEMENT } \\
\text { of acute } \\
\text { menorrhagia in women } \\
\text { with and without } \\
\text { underlying bleeding } \\
\text { disorders: consensus } \\
\text { from an international } \\
\text { expert panel. Eur J } \\
\text { Obstet Gynecol Reprod } \\
\text { Biol 2011;158:124-34. }\end{array}$ & $\begin{array}{l}1.3 \mathrm{~g} \text { orally } \\
\text { or } \\
10 \mathrm{mg} / \mathrm{kg} \mathrm{IV} \\
\text { (maximum } \\
600 \mathrm{mg} / \mathrm{dose})\end{array}$ & $\begin{array}{l}\text { Three times per } \\
\text { day for } 5 \text { days } \\
\text { (every } 8 \text { hour ) }\end{array}$ & $\begin{array}{l}\text { Contraindications include, but } \\
\text { are not limited to acquired } \\
\text { impaired color vision and } \\
\text { current thrombotic or } \\
\text { thromboembolic disease. } \\
\text { The agent should be used with } \\
\text { caution in patients with a history } \\
\text { of thrombosis (because of } \\
\text { uncertain thrombotic risks), and } \\
\text { concomitant } \\
\text { ADMINISTRATION } \Xi \text { of } \\
\text { combined oral contraceptives } \\
\text { needs to be carefully considered. }\end{array}$ \\
\hline
\end{tabular}


Obat antifibrinolitik seperti asam traneksamat merupakan terapi efektif pada pasien dengan PUA kronis. Direkomendasikan untuk menggunakan asam traneksamat oral maupun intravena pada terapi PUA akut. ${ }^{1}$

Ketika episode akut perdarahan sudah terkontrol, pilihan terapi jangka panjang dapat dipertimbangkan untuk mencegah PUA kronis. Terapi jangka panjang efektif termasuk pemakaian alat kontrasepsi dalam rahim (AKDR) dengan levonogestrel, asam traneksamat, dan obat NSAID. Pasien dengan kelainan perdarahan umumnya memberikan respon terhadap terapi hormonal maupun non-hormonal. Konsultasi dengan seorang hematologis direkomendasikan pada pasien-pasien tersebut terutama bila perdarahan sulit dikontrol atau ginekologis tidak memahami pilihan terapi pada pasien dengan kelainan perdarahan. Desmopressin dapat membantu mengangani PUA akut pada pasien dengan penyakit von Willebrand jika pasien tersebut sebelumnya memberikan respon terhadap agen tersebut. ${ }^{15}$ Faktor VIII rekombinan dan faktor von Willebrand juga tersedia dan dapat diperlukan untuk mengontrol perdarahan hebat. Faktor defisiensi spesifik lainnya juga dapat diperlukan. Pasien dengan kelainan perdarahan atau kelainan fungsi platelet sebaiknya menghindari pemakaian obat non-steroid antiinflammatory drugs (NSAID) karena efek agregasi platelet dan interaksi dengan obatobat yang memengaruhi fungsi hati dan produksi faktor pembekuan. ${ }^{16}$

\section{Penanganan operatif}

Penanganan operatif didasarkan pada stabilitas pasien, tingkat perdarahan, kontraindikasi penanganan medis, dan kondisi medis yang ada. Penanganan operatif termasuk dilatasi dan kuretase, ablasi endometrial, embolisasi arteri uterina, dan histerektomi. ${ }^{1}$

\section{Simpulan dan rekomendasi}

Etiologi PUA akut sebaiknya diklasifikasikan berdasarkan sistem PALM-
COEIN. Penanganan medis menjadi terapi awal bila tidak ada kontrindikasi. Pilihan yang ada termasuk EEK intravena, regimen multidosis PKK dan progestin oral, dan asam traneksamat. Keputusan pilihan harus berdasarkan riwayat medis pasien dan kontraindikasinya.

Penanganan operatif didasarkan pada stabilitas pasien, tingkat perdarahan, kontraindikasi terhadap penanganan medis, kurangnya respon terhadap penanganan medis, dan riwayat medis yang ada. Pilihan terapi operatif sebaiknya didasarkan pada faktor-faktor tersebut. Bila perdarahan akut sudah ditangani direkomendasikan untuk melakukan transisi pada penanganan jangka panjang.

\section{DAFTAR PUSTAKA}

1. ACOG committee opinion No. 349, November 2006: Menstruation in girls and adolescents: using the menstrual cycle as a vital sign. American College of Obstetricians \& Gynecologists. Obstet Gynecol. 2006;108(5):1323-8.

2. He Q, Kalberg J. BMI in childhood and its association with height gain, timing of puberty and final height. Pediatr Res. 2001;49:244-51.

3. Chumlea WE, Schubert CM, Roche AF, Kulin HE, Lee PA, Himes JH, et al. Age at menarche and racial comparisons in US girls. Pediatrics. 2003;111:110-3.

4. Munro MG, Critchley HO, Broder MS, Fraser IS. FIGO classification system (PALM-COEIN) for causes of abnormal uterine bleeding in nongravid women of reproductive age. FIGO Working Group on Menstrual Disorders. Int J Gynaecol Obstet. 2011;113:3-13.

5. Holland-Hall C. Heavy menstrual bleeding in adolescent: normal variant or a bleeding disorder. Contemp Pediatr. 2012;29(11): 24-40.

6. FIGO Working Group on Menstrual Disorder. FIGO Classification System (PALMCOEIN) for causes of abnormal uterine bleeding in nongravide women od reproductive age. Int $\mathbf{J}$ Gynecol Obstet. 2011;113:3-13.

7. James AH. Bleeding disorders in adolescents. Obstet Gynecol Clin North Am. 2009;36(1):153-62. 
8. Shankar M, Lee CA, Sabin CA, Economides DL, Kadir RA. Von Willebrand disease in women with menorrhagia: a systematic review. BJOG 2004;111(7):734-40.

9. Dilley A, Drews C, Lally C, Austin H, Barnhart E, Evatt B. A survey of gynecologists concerning menorrhagia: perceptions of bleeding disorders as a possible cause. J Womens Health Gend Based Med. 2002;11(1):39-44.

10. Munro MG, Lukes AS. Abnormal uterine bleeding and underlying hemostatic disorders: report of a consensus process. Fertil Steril. 2005;84(5):1335-7.

11. Strickland JL, Wall JW. Abnormal uterine bleeding in adolescents. Obstet Gynecol Clin North Am. 2003;30:321-5.

12. Hale GE, Manconi F, Luscombe G, Fraser IS. Quantitative measurements of menstrual blood loss in ovulatory and anovulatory cycles in middle- and latereproductive age and the menopausal transition. Obstet Gynecol. 2010;115(2 Pt
1):249-56.

13. Nichols WL, Rick ME, Ortel TL, Montgomery RR, Sadler JE, Yawn BP, et al. Clinical and laboratory diagnosis of von Willebrand disease: a synopsis of the 2008 NHLBI/NIH guidelines. Am J Hematol. 2009;84(6): 366-70.

14. National Collaborating Centre for Women's and Children's Health, National Institute of Clinical Excellence. Heavy menstrual bleeding. Clinical guideline. London: RCOG Press, 2007.

15. Kadir RA, Lukes AS, Kouides PA, Fernandez H, Goudemand J. Management of excessive menstrual bleeding in women with hemostatic disorders. Fertil Steril 2005;84(5):1352-9.

16. ACOG Committee Opinion No. 451: Von Willebrand disease in women. American College of Obstetricians and Gynecologists. Obstet Gynecol 2009;114:1439-43. 